\title{
sciendo
}

\section{An analysis of the economic performances of the retail companies in Romania}

\author{
Mihail BUSU \\ Bucharest University of Economic Studies, Bucharest, Romania \\ mihail.busu@fabiz.ase.ro \\ Madalina Vanesa VARGAS \\ Bucharest University of Economic Studies, Bucharest, Romania \\ vanesa.vargas@fabiz.ase.ro \\ Ioan Alexandru GHERASIM \\ Corvinus University of Budapest, Budapest, Hungary \\ ioanalexandrugherasim@yahoo.com
}

\begin{abstract}
Based on the finding of the economic studies on the analysis of the performances of the companies from retails sector, this paper aims of analyzing the economic factors which are the basis of economic performances of the new companies from the retails sector of Romania. Starting with an econometric model based on current assets, fixed assets and number of employees, three research hypotheses were tested and validated through a multilinear regression model analyzed with the OLS method with the use of statistical software SPSS 23. The conclusions of the paper are in line with the other researches in the area and underline that the economic performances of the selected companies are determined by the current and fixed assets, as well as the number of employees.
\end{abstract}

Key-words: financial performances, retail companies, regression analysis.

Please cite the article as follows: Busu, M., Vargas, M.V., Gherasim, I.A. (2020), "An analysis of the economic performances of the retail companies in Romania", Management \& Marketing. Challenges for the Knowledge Society, Vol. 15, No. 1, pp. 125-133, DOI: 10.2478/mmcks-20200008.

\section{Introduction}

Retail sector is one of the most important sectors in the world. In Romania, the retail sector represented 18\% of the GDP and had an annual growth of 8,3\% in 2019 (European Commission, 2019). The gross sales of the retail stores exceeded 45 billion euro in 2018, where the largest retail stores are in the food sector.

Retail is the manner by which makers of services and products get their items to the shopper. Retailers frequently get their products from the producer. That is the point at which an item turns into a finished product. Retailers can likewise purchase items from a go between, known as a distributer or merchant. The wholesaling organization consolidates the items from around the globe. It repackages them for simpler distribution and marketing. Retailers are the last stop on the store network before the items end up in your shopping basket. Retailers bring in cash by raising costs well over their expense of labor. Everybody along the store network does likewise. Retailers can get more cash-flow in the event that they sidestep the distributer and buy straightforwardly from the manufacturing plant. Some big retailers regularly make best buy products by themselves.

Romania's financial development eased back to only $4 \%$ in 2018 , a lower rate than anticipated at the start of the year by the analysts and government. The downtrend in the 
economy was already able to be found in specific areas, for instance real estate and construction. In fact, what's going on in the real estate industry is regularly a marker of the general financial climate. However, for retailing the story seems quite different. It had a better performance, where the growth exceeded the expectations. Progressing development will be driven by different variables, including the lasting extension of retail xchains, especially in towns with smaller population and in the rural area where family businesses are replaced with bigger retails chains.

As indicated by the National Institute of Statistics, between September 2017 and September 2018, the net compensation expanded by over $13 \%$. This was a measure from which many retailing companies profited. The minimum wage also increased in the last two years, another instrument that helped the consumption growth. On the other hand, the low unemployment rate of $4 \%$ in October 2019 according to Eurostat creates a workforce crisis. Given our hypothesis that the number of employees has a direct consequence to the performance of the company, this unemployment rate might affect the retail sector.

Despite the fact that the primary analysts have decreased the chances for a future growth forecast estimated for the Romanian economy, the nation's retailing industry is required to keep on exceeding its economy. One reason for this is the fact that the retail sector has not been penetrated by the big outlet shops. Nonetheless, the retail sector in Romania will keep growing, but the consumption rate remains lower compared to the other EU member states. What's more, as retailers keep on putting resources into web and other portable instruments, the number of potential clients will grow, and with them the incomes. The expanding use of web is being reflected in the wide-scale appropriation by retailers of an omni-channel approach as they hope to profit of the progress in innovation and changing customer ways of life.

However, most of the retail sector hold its activity linked to the physical stores, as the case in Romania. More than $90 \%$ of the retail companies activates in the physical environment and only $8 \%$ of the total retailing started to sell its goods or services also in the online sector. This is the motivation behind our assumption that the number of employees in a company is an important factor that strongly affects its performance. This is one of the reasons why also the fixed assets and the current assets still have a tremendous impact in the economic performance and efficiency of this sector, as our paper highlights. The value of the assets is an important factor because it might influence the company capacity of remodeling itself if something goes wrong, its capability to invest in innovations and high technology, therefore increase the effectiveness and eventually the economic performance of the company.

The efficiency of a company is very important and given the fact that only $57 \%$ of the overall electronic retail companies are noticed as efficient, more studies must be conducted in order to understand the growth of the economy and prevent a possible crisis.

The current research investigates the relationship between three internal factors of a retail firm (number of employees, current assets and fixed assets) and the net profit of the company. As for the structure of the paper, first we analyzed the existent literature, then we introduced our hypothesis, which were tested and in the end the results were reviewed. We used three internal factors to build our hypothesis as follows: (1) Current assets have a significant impact on the net profit of the retail companies; (2) Fixed assets have a significant impact on the net profit of the retail companies; (3) Number of employees have a significant impact on the net profit of the retail companies. The multiple linear regression model was applied for retail companies in order to test our hypothesis. The aim of this paper is to prove that the internal factors of a retail company, not just the 
customer satisfaction or the macroeconomic factors, have an impact on the profitability of the company.

\section{Literature review}

Due to increased competition, retail companies are increasingly thinking about the methods and techniques that will help them, first, to attract new customers, and second, not to lose existing ones. The current study analyzes the internal factors of a company that will influence the economic performance of the sector. Of course, the impact of external factors like the business-universities alliances (Dima, et al., 2017), the leadership (Dima and Ghinea, 2016), the role of knowledge intensive business services (Busu \& Busu, 2017) or unemployment (Trasca et al., 2019) was well studied and discovered a direct relationship influencing the business area. In his latest works, David L. Huff described a model for determining the attractiveness of retailers, which presents the ratios that can be used to calculate market share of the studied retailers in the product category (Huff, 2003). To solve the problem of predicting the attendance of retailers, mathematical models are used, which determine the probability that a particular group of consumers selects the retailer. Such methods include: Reilly, (1931), Nakanishi \& Cooper (1974), McFadden(1973), Scott, (2017), Rust \& Donthu, (1995), Hernandez, Biasiotto, (2001) and (Busu \& Nedelcu, 2018). The role of such position papers is multiple (Hoinaru and Stanila, 2019).

One of the aspects of management's internal processes is to create a balance between employee empowerment and teamwork. Rewarding employees through incentives based on performances is being done by a lot of firms to motivate them however at the same time making them work in a team is what organizations should encourage to achieve organizational goals (Campbell, 2003). The employees are one of the elements whose interactions with the customer act as a moderator to have a profound impact on trusting various practices for building customer relations (Plakoyiannaki, 2008). Organization's performance affects an employee's behavior. Organization's performance is a result of top management's decision making and its implementation. Organizational factors with the aid of technological factors affect performance (Rafiki et al., 2019). However, the hypothesis studied in this research will demonstrate the vice versa of this theory, where the number of employees affects the organizational performance on one's firm.

Most of the studies analyze the performance of retail companies through the customer experience, where the consumer is the point of sale and the potential growth of the company. Abratt and Kleyn (2012) go further when they say that managing the company's corporate brand experience as a source of differentiation can provide a competitive advantage due to its ability to create long-term brand differentiation.

There is a research gap that can be observed in the literature related to the connections between internal factors of a retail company and its net profit. However, Huang et al. (2019) validates through their research our hypothesis, where using a sample of more than 3000 firms determined there is a significant connection between employee's treatment score and net profits. A more recent study examines the employee satisfaction related to retailer profitability (Briggs et al., 2020).

Evidence by Costea (2016) suggests that the Romanian retail sector is quite developed, as in quantitative terms the products on which Romanian consumers have had $19 \%$ more expenses with in year 2016, compared to the previous year, were beverages and food, accounting for almost 28\%, goods that are not included in the nourishment 
supplies category, that reached $16.1 \%$, and vehicle fuel, which have been upscaled to nearly $10 \%$.

In terms of the aspects that have permitted the growth of the companies operating in this field, Pantea et al. (2014) authenticate that an improvement in the degree of capital intensiveness, namely assets, and in the organization's personnel, are positively contributing to the alleviation of the organizational performance, when it is measured by reference to financial indicators such as return on assets (ROA) and return on equity (ROE). Additional supportive proof is brought by the work of Cârstea et al. (2017), who hypothesize and demonstrate that an organization's number of employees influences the entity's net profit to a statistically significant extent. However, when it comes to fixed assets, no linkage in between it and net profit could be identified.

Focusing on further implications of the commercial monetary effectiveness of the organizations activating in the Romanian retail field, Cârstea et al. (2018) note that the productivity of the work conducted and the individual net profit established for each employee are defining variables that pose implications upon their commercial monetary degree of efficiency.

Utilizing a financial ratio approach and being concerned on financial returns, the study conducted by Batrancea et al. (2018) indicates that ratios such as return on sales and return on assets, as well as the ratio of inventory and of receivables reflect a negative association. Also, studying retail companies in Latvia, Berzkalne and Zelgalve (2014), find out that the size of the organization is positively correlated with return on equity (ROE), while the work performed by Blažková and Dvouletý (2018) pinpoints that the company size poses a positive influence upon the economic standing in the case of Czech companies belonging to the food handling sector.

\section{Methodology}

In order to analyze the economic performances of the retail companies in Romania, a sample of 68 companies were selected. A systematic random sampling technique was applied to extract the sample from the population, which is represented by all retail companies in Romania. For these companies we have used secondary data, which was collected from the Ministry of Finance's website. From this website, we have collected the financial reports of the selected companies in 2016, the most recent year of data availability. The period of the econometric analysis was during the first two months of year 2020.

Starting from the research articles mentioned in the literature review section, we will focus our analysis on the research question: "What are the main factors of the economic performances of the new retail companies in Romania?". In addition, we will try to estimate which of the three exogenous factors impacting the economic performances, namely: current assets, fixed assets and number of employees has the greatest impact on the endogenous variable of the regression model.

In order to quantify the impact analysis, there will be formulated three research hypotheses, which are formulated in Table 1.

Table 1. Hypothesis of the research study

\begin{tabular}{|l|l|}
\hline Hypothesis 1 & Current assets have a significant impact on the net profit of the retail companies \\
\hline Hypothesis 2 & Fixed assets have a significant impact on the net profit of the retail companies \\
\hline Hypothesis 3 & Number of employees have a significant impact on the net profit of the retail companies \\
\hline
\end{tabular}


To test the above statistical hypotheses, we will use a multiple linear regression model with longitudinal data. The model has net profit as a proxy for economic performances as the dependent variable and three independent variables: current assets, fixed assets and number of companies in the retail sector.

In conclusion, the regression model (Sen and Srivastava, 1990) is defined as follows:

$$
Y_{i}=\alpha+X_{i j} \beta_{j}+\varepsilon_{i}, i=\overline{1, N}, j=\overline{1, k},
$$

where

- $\quad I=$ a cross-section dimension (transversal section), $\mathrm{j}=$ number of exogenous variables;

- $\quad \mathrm{N}=$ is the number of companies in our model;

- $Y_{i t}=$ endogenous variable;

- $X_{i}=$ the $\mathrm{i}^{\text {th }}$ observation of the exogenous variables;

- $\beta_{0}, \beta_{1}, \beta_{2}, \ldots, \beta_{k}=$ parameter coefficients;

- $\varepsilon_{i}=$ white noise.

The regression analysis is using transversal data. In our study, we have selected 68 retail companies using the random simple method from a total of 120 companies. The data was selected from the website www.listafirme.ro from November to December 2019.

In conclusion, the regression model is as follows:

Net profit $=\beta_{0}+\beta_{1}$ (Current assets) $+\beta_{2}$ (Fixed assets) $+\beta_{3}$ (Number of employees)

in which:

- $\quad$ Net profit - the endogenous variable

- $\quad$ Current assets - exogenous variable

- $\quad$ Fixed assets - exogenous variable

- $\quad$ Number of employees - exogenous variable

\section{Results}

The multiple linear regression equation used to test the three research hypotheses was accomplished using the Ordinal Least Square method. We have used this method to analyze the economic performances of the retail companies in Romania. The model parameters were estimated with the SPSS 23 software.

A description of the regression model can be observed in the below table.

Table 2. Statistical description of variables in the model

\begin{tabular}{|c|c|c|c|}
\hline Variable & Mean & Std. deviation & $\mathbf{N}$ \\
\hline $\mathrm{Y}$ & 384.50 & 419.31 & 68 \\
\hline $\mathrm{X}_{1}$ & 476.00 & 110.21 & 68 \\
\hline $\mathrm{X}_{2}$ & $47,055.00$ & $43,318.19$ & 68 \\
\hline $\mathrm{X}_{3}$ & 2.59 & 1.58 & 68 \\
\hline
\end{tabular}

Source: Authors own computation harnessing SPSS 23

The matrix correlation could be seen in Table 3.

Table 3. Matrix of correlation

\begin{tabular}{|l|l|l|l|l|l|}
\hline \multicolumn{6}{|l|}{ Correlations } \\
\hline \multicolumn{2}{|l|}{} & $\mathrm{Y}$ & $\mathrm{X}_{1}$ & $\mathrm{X}_{2}$ & $\mathrm{X}_{3}$ \\
\hline & $\mathrm{Y}$ & 1 & .789 & .678 & .865 \\
\hline
\end{tabular}

Vol. 15, No. 1, Spring, pp. 125-133, ISSN 2069-8887| Management \& Marketing. Challenges for the Knowledge Society 


\begin{tabular}{l|l|l|l|l|l|}
\multirow{3}{*}{$\begin{array}{l}\text { Pearson } \\
\text { Correlation }\end{array}$} & $\mathrm{X}_{1}$ & .789 & 1 & .098 & .064 \\
\cline { 2 - 6 } & $\mathrm{X}_{2}$ & .678 & .098 & 1 & .086 \\
\cline { 2 - 7 } & $\mathrm{X}_{3}$ & .865 & .064 & .086 & 1 \\
\hline
\end{tabular}

Source: Authors own computation harnessing SPSS 23

From the above table we could observe the independent variables are highly correlated with the independent variable and low correlated to each other.

Analyzing the economic performances of the retail companies in Romania through the independent variables (current assets, fixed assets and number of employees), the following equation was obtained through the analysis of multiple linear regression (see table 4): $\mathrm{Y}=-3.219+0.215\left(\mathrm{X}_{1}\right)+0.033\left(\mathrm{X}_{2}\right)+0.768\left(\mathrm{X}_{3}\right)$.

Table 4. Estimation of the regression coefficients

\begin{tabular}{|c|c|c|c|c|c|c|c|c|}
\hline \multicolumn{9}{|c|}{ Coefficients $^{\mathbf{a}}$} \\
\hline & & \multicolumn{2}{|c|}{$\begin{array}{c}\text { Unstandardized } \\
\text { Coefficients } \\
\end{array}$} & $\begin{array}{c}\text { Standardized } \\
\text { Coefficients }\end{array}$ & \multirow[b]{2}{*}{$\mathrm{t}$} & \multirow[b]{2}{*}{ Sig. } & \multicolumn{2}{|c|}{ Collinearity Statistics } \\
\hline \multicolumn{2}{|c|}{ Model } & B & $\begin{array}{l}\text { Std. } \\
\text { Error }\end{array}$ & Beta & & & Tolerance & VIF \\
\hline \multirow[t]{4}{*}{1} & (Constant) & -3.219 & 1.860 & & 2.549 & .812 & & \\
\hline & $\mathrm{X} 1$ & 0.215 & 1.679 & 1.642 & 1.727 & .023 & .718 & 1.105 \\
\hline & $\mathrm{X} 2$ & 0.033 & 1.543 & 0.358 & 0.727 & .008 & .768 & 1.138 \\
\hline & $\mathrm{X} 3$ & 0.768 & 1.124 & 1.107 & 1.132 & .012 & .864 & 1.201 \\
\hline
\end{tabular}

a. Dependent Variable: Y.

Source: Authors own computation harnessing SPSS 23

Then, SPSS 23 software was used to test the Variance Inflection factor (VIF) for each explanatory variable in the model (table no. 4). All four values $(1.860,1.679,1.543$ and 1.124) are lower than 3 which make us conclude that the explanatory variables are not correlated with each other. This complements the results in the table 3 , the correlation coefficients matrix between the explanatory variables are small.

We could also observe that all four independent variables in the model are significant at Significance level of 95\%, as all p_values are less that the 0.05 threshold.

The estimation of the regression model could be seen in Table 5.

Table 5. The estimation of the econometric model

\begin{tabular}{|l|l|l|l|l|l|}
\hline \multicolumn{5}{|l|}{ Model Summaryb } \\
\hline Model & $\mathrm{R}$ & R_Square & $\begin{array}{l}\text { Adjusted R_ } \\
\text { Square }\end{array}$ & $\begin{array}{l}\text { Std. Error of the } \\
\text { Estimate }\end{array}$ & Durbin-Watson \\
\hline 1 & $.834^{\mathrm{a}}$ & .696 & .658 & .3450 & 2.025 \\
\hline
\end{tabular}

a. Predictors: (Constant), X4, X3, X2, X1

b. Dependent Variable: Y

Source: Own evaluation based on SPSS 23

From the table above we could see that the model does not have autocorrelation errors as the value of Durbin-Watson statistical test ( $D W=2.025$ ) is close to 2. The multiple correlation coefficient value $(\mathrm{R}=0.834)$ is close to 1 , which means that there is a direct and positive correlation between the variables in the model. Moreover, the coefficient of determination (R_Square $=0.696$ ) shows that $69.6 \%$ of the variation of the dependent variable in the model is explained by the variability of the three independent variables, and hence, the remaining $30.4 \%$ is explained by other unknown factors.

The validity of the model is calculated using Fisher test. In Table 6 we could see that the $\mathrm{p}_{-}$value of the test (Sig. $\mathrm{F}=0.024$ ) is lower than the 0.05 threshold, so we could conclude that at $95 \%$ confidence level the regression model is valid. 
Table 6. ANOVA Table

\begin{tabular}{|c|c|c|c|c|c|c|}
\hline \multicolumn{7}{|c|}{ ANOVAa } \\
\hline \multicolumn{2}{|c|}{ Model } & $\begin{array}{l}\text { Sum of } \\
\text { Squares }\end{array}$ & $\mathrm{df}$ & Mean Square & $\mathrm{F}$ & Sig. \\
\hline \multirow[t]{3}{*}{1} & Regression & 32.072 & 3 & 8.333 & 7.440 & $.024^{\mathrm{b}}$ \\
\hline & Residual & 23.651 & 25 & 1.120 & & \\
\hline & Total & 54.129 & 28 & & & \\
\hline
\end{tabular}

a. Dependent Variable: $Y$

b. Predictors: (Constant), X4, X3, X2, X1

Therefore, from the above results, we could conclude that the model is correctly specified and valid, and that the independent factors are significant for the economic performances of the retail companies in Romania, because the estimated coefficients are significantly different than zero, the model is valid, the errors are not autocorrelated, the explanatory factor are independent and the model explains most of the variation of the economic performances of the selected companies.

Thus, according to the statistical results, all three research hypotheses $\left(\mathrm{H}_{1}, \mathrm{H}_{2}\right.$ and $\left.\mathrm{H}_{3}\right)$ from Table 1 were valid.

\section{Conclusions}

Economic literature and the econometric analysis performed in this study, lead to the conclusion that current assets, fixed assets and number of employees are significant factors of the net profit of the new companies in the retail sector of Romania.

The estimation of the econometric model reveals that the economic performance of the retail companies in Romania could be explained by the selected indicators. Our results are in line with recent studies in this area (Tuzen and Zhang, 2017; Tamulevičienè, 2016) and confirm that the economic performances of the companies in the retail sector could be determined by the current and fixed assets, as well as the number of employees.

The multiple linear regression model reveals that an increase of 1 percentage point (pp) of the current assets would lead to an increase of $0.215 \mathrm{pp}$ of the net profit of the retail companies, while an increase of 1 percentage point (pp) of the fixed assets would lead to an increase of $0.033 \mathrm{pp}$ of the net profit of the retail companies and an increase of 1 percentage point (pp) of the number of employees would lead to an increase of 0.768 pp of the net profit of the retail companies.

Since the calculation of the indicators used in the regression analysis covered a period of one year, the main limitation of this research is related to the time database used for the factor analysis. Therefore, future research should be conducted for longer periods of time which may provide a more accurate picture of the model indicators. Also, other independent factors or methods of analysis, could be performed to give a better picture of the performances of the new retail companies in Romania.

\section{References:}

Abratt, R.; Kleyn, N. (2012). “Corporate identity, corporate branding and corporate reputations: Reconciliation and integration", European Journal of Marketing, Vol. 46, no. 7/8, pp. 1048-1063.

Batrancea, I., Morar, I.-D., Masca, E., Sabau, C., \& Bechis, L. (2018). Econometric modeling of SME Performance. Case of Romania. Sustainability, 10(1), 192. https://doi.org/10.3390/su10010192. 
Berzkalne, I., \& Zelgalve, E. (2014). Return on equity and company characteristics: an empirical study of industries in Latvia. The 8th International Days of Statistics and Economics, Prague, September 11-13, 2014, 94-103.

Blažková, I., \& Dvouletý, O. (2018). Sectoral and Firm-Level Determinants of Profitability: A Multilevel Approach. International Journal of Entrepreneurial Knowledge, 6(2), 32-44.

Busu, C., \& Busu, M. (2017). The role of knowledge intensive business services on Romania's economic revival and modernization at the regional level. Sustainability, 9(4), 526.

Busu, M., \& Nedelcu, A. C. (2018). Sustainability and Economic Performance of the companies in the renewable energy sector in Romania. Sustainability, 10(1), 8.

Campbell, A. J. (2003). Creating customer knowledge competence: managing customer relationship management programs strategically. Industrial marketing management, 32(5), 375-383.

Cârstea, G., Corboş, R.- A., Popescu, R. - I., \& Bunea, O. - I. (2017). Analysis of the influence of some indicators on the profitability of the FMCG retail market in Romania. Proceedings of the 11th International Management Conference "The Role of Management in the Economic Paradigm of the XXIst Century", 11, 481492.

Cârstea, G, Corboş, R.- A, Măiţă, N.D., \& Bunea, O. - I. (2018). In the quest for competitiveness: the influence between financial indicators and the rate of commercial profitability (RCP) in the Romanian retail market. Conference Proceedings: 2nd International Scientific Conference ITEMA 2018, 446-453.

Costea, M. (2016). Consumption-based economy. The case of Romania in the last two decades. Ecoforum, 5, 56-63.

Dima A.M. Ghinea V.M. A model of academic leadership Proceedings of the 12 th European Conference on Management Leadership and Governance 10-11 november 2016 Retrieved from http://www.academicconferences.org/conferences/ecmlg/.

Dima A., Hadad S., Luchian I. (2017) "Review on the dimensions of business-university alliances" Proceedings of the 11th International Conference on Business Excellence pp. 64-73 DOI: 10.1515/picbe-2017-0007.

European Commission, (2019). Raportul de țară din 2019 privind România, inclusiv un bilanț aprofundat referitor la prevenirea și corectarea dezechilibrelor economice (pp. 9), available at: https://ec.europa.eu/info/sites/info/files/file_import/2019european-semester-country-report-romania_ro.pdf.

Hernandez, T., \& Biasiotto, M. (2001). Retail location decision-making and store portfolio management. Canadian Journal of Regional Science, 24(3), 399-421.

E. Kaili et al. (2019), New Models of Financing and Financial Reporting for European SMEs, Chapter 1: The SMEs Literature Review: Perspective of Studies, https://doi.org/10.1007/978-3-030-02831-2_1

Huff D.L. (1963) A Probabilistic Analysis of Shopping Center Trade Areas. Land Economics. Vol. 39, № 1. 1963. pp. 81-90 Available at: http://www.jstor.org/discover/10.2307/3144521?uid=3738936\&uid=2\&uid=4 \&sid=21102716073273

Huff, D. L. (2003). Parameter estimation in the Huff model. ESRI, ArcUser, 34-36.. URL: http://www.esri.com/news/arcuser/1003/files/huff.pdf

McFadden, D. (1973). Conditional logit analysis of qualitative choice behavior. Frontiers in Econometrics, ed. P. Zarembka, Academic Press, New York. 1974. P. 105-142. 
Pantea, M., Gligor, D., \& Anis, C. (2014). Economic determinants of Romanian firms' financial performance. Procedia - Social and Behavioral Sciences, 124, 272-281.

Plakoyiannaki, E., Tzokas, N., Dimitratos, P., \& Saren, M. (2008). How critical is employee orientation for customer relationship management? Insights from a case study. Journal of Management Studies, 45(2), 268-293

Rafiki, A., Hidayat, S. E., \& Al Abdul Razzaq, D. (2019). CRM and organizational performance: A survey on telecommunication companies in Kuwait. International Journal of Organizational Analysis, 27(1), 187-205

Reilly W. J. (1931) The Law of Retail Gravitation / W. J. Reilly New York: Knickerbrocker Press

Rust, R. T., \& Donthu, N. (1995). Capturing geographically localized misspecification error in retail store choice models. Journal of Marketing research, 103-110.

Scott, P. (2017). Geography and Retailing (Vol. 137). Transaction Publishers.

Sen, A., \& Srivastava, M. (1990). Multiple regression. In Regression Analysis (pp. 28-59).

Springer, Berlin, Heidelberg.

Tamulevičienè, D. (2016). Methodology of complex analysis of companies' profitability. Entrepreneurship and sustainability issues, 4, 53-63.

Trasca, D.L., Stefan, G., Aceleanu, M.I., Sahlian, D.N., Stanila, G. O., Hoinaru, R., (2019), Unique Unemployment Insurance Scheme in Euro Zone. Terms and Conditions. Impact, Economic Computation and Economic Cybernetics Studies and Research, Issue 2/2019; Vol. 53.

Tuzel, S., \& Zhang, M. B. (2017). Local risk, local factors, and asset prices. The Journal of Finance, 72(1), 325-370. 